\title{
RES VERA AGITUR \\ ON THE STRUCTURE AND THE TARGETS OF JUVENAL'S SATIRE 4
}

\begin{abstract}
Summary: Satire 4 is one of the most-criticized poems of Juvenal. Because of its structural problems, certain scholars have even casted doubts on its unity considering it as two fragments patched together by a later editor. The key to understand the satire's structure is the connection between its two main parts and the central figures thereof, Crispinus and Domitian. Apart from the structural problems, this paper also deals with certain features of the mock-epic as well as the targets of the invective.
\end{abstract}

Key words: Domitian, Juvenal, mock-epic, Statius, satire, Satire 4

Juvenal's Satire 4, similarly to Satire $12,{ }^{1}$ is often criticized because of its structure. ${ }^{2}$ Certain scholars consider it as two fragments patched together, while others detect only a loose connection between its two parts: the first 27 lines on the crimes of Crispinus and the mock-epic on the giant turbot brought to Domitian. ${ }^{3}$ In this paper, besides briefly summarizing the most important steps towards the explanation of the connection between the two parts of the poem, I also deal with Crispinus' figure and his role in the poem in detail, present the distinctive features on the turbot-epic and look at the different targets of the satire's invective, as well as its role in Juvenal's Book One as a whole.

* The research has been conducted with the support of MTA-SZTE Antiquity and Renaissance: Sources and Reception Research Group (TK2016-126).

${ }^{1}$ E.g. Courtney, E.: A Commentary on the Satires of Juvenal. London 1980, 517; DE LABRIOLle, P. (ed.): Les satires de Juvénal. Paris 1932, 298; HelmbOLD, W. C.: Juvenal's Twelfth Satire. CPh 51 (1956) 15-16.

${ }^{2}$ E.g. DuFF, J. D. (ed.): D. Iunii Iunenalis Saturae XIV. Cambridge 1900, 173; DE DECKER, J.: Juvenalis declamans. Ghent 1912, 74. Cf. LEWIS, J. D. (ed.): D. Iunii Iuvenalis Satirae. London 1882, II 448, on Satires 4 and 11: "No doubt both these satires would be improved by losing their prologues."

${ }^{3}$ For the research on Satire 4 before 1957, see ANDERSON, W. S.: Studies in Book I of Juvenal. In Essays on Roman Satire. Princeton 1982, 232-234. 
The first step was taken by Stegemann. According to his interpretation, the first section of the satire exhibiting the serious and less serious sins of Crispinus serves as an introduction to the mock-epic. The chiastic structure of the satire - scelera, nugae, nugae, scelera - is also presented by Stegemann: ${ }^{4}$ the poem begins with Crispinus' serious crimes (1-10), followed by his less serious acts (facti leviores: 11-27). The third section is the mock-epic itself, dealing with the lesser faults of Domitian (nugae: 37-149), while the poem's closure briefly refers to the emperor's real crimes that are, of course, much more serious than those of Crispinus $(150-154) .^{5}$

Nearly half a century later, Helmbold and O'Neil presented the connection between the satire's two parts in detail: the structure is held together by three links between Crispinus and Domitian, namely the common motif of the big fish, ${ }^{6}$ the $n u g a e-$ scelera distinction between their deeds, and there are also a handful of similarities between the two characters. Both of them spent their early years in poverty; they were overly conscious of their appearance, adored luxury, desired for the wives of other men, committed incest, and neither of them is "redeemed by a single virtue". 7 The connection between the two characters is enlightened by the conclusions of Helmbold and O'Neil: ${ }^{8}$ Crispinus is a miniature reflection of Domitian, ${ }^{9}$ while his behaviour is (using Gowers' words) the "hors-d'oeuvre", served before the main course, i.e. the acts of the "bald Nero" $(4,38$ : calvo... Neroni $) .{ }^{10}$

However, not all of the structural problems are solved by the connection between Crispinus and Domitian. The first 33 lines of the poem preceding the mockepic can be divided into two parts: lines 1-27 focus on Crispinus' character, while lines 28-33 serve as transition towards the turbot-epic - it must be noted that while certain editors start a new paragraph after line 36, which is the end of Juvenal's peculiar invocation of the Muse, lines 34-36 unambiguously belong to the mock-epic. ${ }^{11}$ The main question concerning the structure is the following: what is the function of the Crispinus-passage? Or more precisely, why do these $27+6$ lines precede the invocation of the mock-epic?

${ }^{4}$ StegemanN, W.: De Iuvenalis Dispositione. Leipzig 1913, 30-36.

${ }^{5}$ Cf. ANDERSON (n. 3) 235: "(Stegemann) failed to note the important difference in degree between the scelera, a difference which directly affects Juvenal's thematic exposition."

${ }^{6}$ As it is also emphasized by BRAUND, S. M.: Juvenal Satires Book I. Cambridge 1996, 273, the big fish is related to a flaw in both cases, but it is not enough for proving the poem's unity on its own.

${ }^{7}$ For the parallels in detail, with ancient quotations, see HELMBOLD, W. C. - O'NEIL, E. N.: The Structure of Juvenal IV. AJPh 77 (1956) 68-73.

${ }^{8}$ KENNEY, E. J.: The First Satire of Juvenal. PCPhS 8 (1962) 30-31 criticizes HeLMBOLD and O'NEIL because of using other authors' texts instead of Juvenal's for Domitian. His arguments are convincingly refuted by TOWNEND, G. B.: The Literary Substrata to Juvenal's Satires. JRS 63 (1973) 155.

${ }^{9}$ Helmbold-O'NeIL (n. 7) 70, cf. BRAUND (n. 6) 274: "The most convincing reading of the poem is to see Crispinus as a microcosm of Domitian..."; HEILMANN, W.: Zur Komposition der vierten Satire und des ersten Satirenbuches Juvenals. RhM 110 (1967) 365: "Crispinus ist einerseits ein kleiner Domitian, andererseits präludiert er der Schilderung des Fischfangs und des Thronrats..." TOWNEND (n. 8) 155-156 deals with the linking points between Crispinus and Nero, and between Domitian and Nero as well.

${ }^{10}$ Gowers, E.: Black Pudding: Roman Satire. In The Loaded Table: Representations of Food in Roman Literature. Oxford 1993, 206.

${ }^{11}$ Cf. BRAund (n. 6) 270. 
The function of the poem's first section can be explained with the help of the analyses of Kilpatrick and Braund. Lines 1-27, characterized by Juvenalian indignation, introduce the topics of the mock-epic: the turbot-story that exhibits a minor fault of Domitian is preceded by the presentation of Crispinus' minor faults - while the poem is framed by the major crimes of these two. ${ }^{12}$ This interpretation is challenged by Kenney, arguing that the mock-epic is not about Domitian. ${ }^{13}$ His counterargument, however, cannot be accepted: albeit it is true that the emperor's words and acts make up only a very limited part of the narrative,${ }^{14}$ he is unequivocally the main character of the mock-epic, since when in the last few lines his most serious crime, the execution of his own people is referred to, Juvenal's negative picture of the emperor is almost completed by the description of the people around him. Domitian's character is exposed by his 11 counsellors presented only briefly here $(72-118) ;{ }^{15}$ however, one of them, Crispinus gets a much more detailed description in the first section of Satire 4. The function of this passage is to reveal the features and habits of the people closest to Domitian. ${ }^{16}$ Besides this indirect attack making use of the emperor's counsellors, another important aspect of the invective on Domitian is the damage or lack of basic values: instead of libertas, securitas, fides, and virtus, his rule is characterized by dominatio, adulatio, and saevitia. ${ }^{17}$

When Crispinus appears in the mock-epic as one of the 11 counsellors, ${ }^{18}$ Juvenal does not draw the attention of readers on him in any way, and nothing renders him as more important than the other ten. Crispinus is not more despicable than the others; he is only one of the many sycophants of Domitian. Therefore, the satire's opening passage could characterize any one of them. His presence in the emperor's council is crucial for interpreting the poem as a whole, since his second appearance motivates the poem's introduction that starts with the words ecce iterum Crispinus referring to Satire 1, where a vehement attack on Crispinus leads to one of the most emblematic Juvenalian sentences: difficile est saturam non scribere (29).

The structure of Satire 4 is typically Juvenalian in many aspects. An insignificant event, the purchase of a big fish by Crispinus leads to a bigger topic, similarly to Satire 13 beginning with the description of an unpaid debt that serves as a starting

${ }^{12}$ BRAUND (n. 6) 274; KilPATRICK, R. S.: Juvenal's 'Patchwork' Satires: 4 and 7. YCS 23 (1973) 234.

${ }^{13} \operatorname{KeNNEY}$ (n. 8) 30.

${ }^{14}$ Cf. SwEET, D.: Juvenal's "Satire" 4: Poetic Uses of Indirection. California Studies in Classical Antiquity 12 (1981) 285. For a different approach, see FLINTOFF, T. E. S.: Juvenal's Fourth Satire. In Papers of the Leeds International Latin Seminar, Sixth Volume, 1990: Roman Poetry and Drama, Greek Epic, Comedy, Rhetoric. Eds. F. CAIRNS - M. HEATH. Leeds 1990, 121: "For the remainder of the satire, except for a single one-line aside, Domitian occupies centre-stage."

${ }^{15}$ Cf. BRAund, S. H.: Paradigms of Power: Roman Emperors in Roman Satire. In Humour and History. Ed. K. CAMERON. Oxford 1993, 66-67: "It seems evident that throughout the poem the satirist is attacking Domitian by attacking his advisers who, to a greater or lesser extent, are microcosms of the emperor: their characteristics either reflect Domitian's own characteristics or are caused by his characteristics." For the members of the council, see WHITE, P.: Ecce Iterum Crispinus. AJPh 95 (1974) 380-382.

${ }^{16}$ See KilpatRicK (n. 12) 234-235.

${ }^{17}$ This is presented in detail by BRAUND (n. 15) 65-66.

${ }^{18}$ Juv. 4. 108-109: et matutino sudans Crispinus amomo / quantum vix redolent duo funera... 
point of a long consolatio, while Satire 15 passes a judgment on whole humanity after presenting a local conflict. ${ }^{19}$ It is also not uncommon in Juvenal's poetry that the two main structural parts of a poem are not in close connection with each other - it is enough to mention Satires 11 and $12 .{ }^{20}$ The shift between the introduction on Crispinus and the mock-epic is as surprising as the speech of Laronia in Satire 2 or Umbricius' 300-line monologue in Satire 3, instead of which a dialogue can be expected. ${ }^{21}$ Until line 27 , Satire 4 seems to be an invective against gluttony, but after a short transition, the poem suddenly becomes a mock-epic introduced by the strangest invocation of the Muse in Roman literature:

incipe, Calliope. licet et considere: non est cantandum, res vera agitur. narrate, puellae Pierides, prosit mihi vos dixisse puellas. Juv. 4. 34-36

The invocation is utterly different from the epic tradition: Calliope can sit down, ${ }^{22}$ and she does not have to sing, since now she will tell a true story. In this manner, Juvenal opposes his poetry that renders its topic as reality with the target of his parody, and if the subject of his poem is res vera, then epic poetry is untrue poetry accordingly. The invocation does not end with the key sentence of the poem: with an anticlimax, Juvenal adds a cheap joke to this serious sentence that is crucial to the interpretation of the poem. After insulting the epic Muse, he asks for the help of all of the Pierides, naming them as "girls" with a surprising compliment, although it cannot be "true" either in the sense of young, or in the sense of virgin. ${ }^{23}$ Moreover, he even refers to the insincerity of his words: "and let it profit me that I have called you girls".

With these lines, the longest third-person narrative in surviving Roman verse satire, i.e. the mock-epic of Satire 4, begins. While the role of the epic tradition is also significant in other Juvenalian poems, above all in Satires 3 and 12, the mockepic of Satire 4 is distinguished from the others by the use of the conventional elements of the genre, and the narration of the plot. The latter can be divided into three parts: 1) the fisherman catches the turbot and brings it to Domitian (39-71);2) the main problem: no dish is large enough for the fish, therefore a council is called together, and Juvenal gives a catalogue of its members $(72-118) ; 3)$ the council decides to make a bigger dish (119-149). This banal plot fits perfectly to a mock-epic, the first lines of which not only show the characteristics of the grand style but also other features of epic poetry:

${ }^{19}$ GRIFFITH, J. G.: Juvenal, Statius, and the Flavian Establishment. $G \& R 16$ (1969) 135.

${ }^{20}$ For the former, see ibid. $135-136$.

${ }^{21}$ BRAUND (n. 6) 274-275.

${ }^{22}$ Normally, the Muse stands while singing, e.g. Ov. Met. 5. 338-340: surgit et inmissos hedera collecta capillos / Calliope querulas praetemptat pollice chordas / atque haec percussis subiungit carmina nervis. Cf. BUECHELER, F.: Coniectanea de Silio Iuvenale Plauto aliis poetis lat. RhM 35 (1880) 392.

${ }^{23}$ TOWNEND (n. 8) 154; BRAUND (n. 6) 243-244. According to the interpretation of STEWART, R.: Domitian and Roman Religion: Juvenal, Satires Two and Four. TAPhA 124 (1994) 323, the word also refers to the execution of the head Vestal Cornelia, similarly to other passages of this satire. Cf. Juv. 4. 8-10: nemo malus felix, minime corruptor et idem / incestus, cum quo nuper vittata iacebat / sanguine adhuc vivo terram subitura sacerdos? 
cum iam semianimum laceraret Flavius orbem

ultimus et calvo serviret Roma Neroni, incidit Hadriaci spatium admirabile rhombi

ante domum Veneris, quam Dorica sustinet Ancon, implevitque sinus; neque enim minor haeserat illis quos operit glacies Maeotica ruptaque tandem solibus effundit torrentis ad ostia Ponti desidia tardos et longo frigore pingues.

Juv. 4. $37-44$

The use of the words cum iam at the beginning of a line is not uncommon in epic poetry ${ }^{24}$ and it is also worth noting that both of the short passages in Seneca's Apocolocyntosis that parody epic-style time-settings begin with the word iam. ${ }^{25}$ This is followed by the statement of the theme that can also be considered as an in medias res-beginning: incidit Hadriaci spatium admirabile rhombi. The size of the fish is expressed by an epic periphrasis, the constructions Hadriaci... rhombi, Dorica... Ancon and calvo... Neroni recall the traditional epithets of the genre, while in lines 41-44 an elaborated simile describes the turbot. ${ }^{26}$ But no matter how closely the style and the aforementioned elements remind us of epic poetry, the content of these lines is completely incongruous with the genre, and not only because of the ridiculous topic. Even the time-setting distances itself from the traditional Roman epic poems, in which the emperor could not be the "tormentor of the dying world", and Rome could not be the servant of anyone. Form and content are not in unity, and the latter turns out to be the stronger: the mock-epic cannot remain coherent, and the grand style is again and again set aside by Juvenal in order to add satirical commentaries to the plot. The first shift can be observed in lines 45-46:

destinat hoc monstrum cumbae linique magister
pontifici summo. quis enim proponere talem
aut emere auderet, cum plena et litora multo
delatore forent?

Juv. 4. 45-48

While the wording of the first sentence telling that the fisherman wants to give the turbot to the pontifex summus (i.e. Domitian) resembles the grand style, in the next one, the mock-epic and the plot give place to the poet's commentary that ends in line 56 as abruptly as it started: ${ }^{27}$ after the trithemimeral caesura, another epic-style timesetting begins.

\footnotetext{
${ }^{24}$ SwEET (n. 14) 296; BRAUND (n. 6) 244. The latter also highlights the epic structure of lines $37-38$.

${ }^{25}$ Sen. Apoc. 2. 1; 2.4.

${ }^{26}$ SWEET (n. 14) 296. For the epic periphrasis, see also FERGUSON, J.: Juvenal: The Satires. Basingstoke - London - New York 1979, 162; COURTNEY (n. 1) 208; WinkLER, M. M.: The Function of Epic in Juvenal's Satires. In Studies in Latin Literature and Roman History V. Ed. C. DEROUX. Bruxelles 1989, 437; CuRTIS, S.: The Exploitation of the Epic Realm by Roman Satirists. Glasgow 2002, 48.

27 The repeated style-shifts of Satire 4 are discussed in detail by ANDERSON (n. 3) 238-241.
} 


\section{iam letifero cedente pruinis}

autumno, iam quartanam sperantibus aegris, stridebat deformis hiems praedamque recentem servabat; tamen hic properat, velut urgueat auster. Juv. 4. 56-59

These lines show striking similarities to the first of the aforementioned Senecan timesettings: ${ }^{28}$

\section{iam Phoebus breviore via contraxerat arcum lucis et obscuri crescebant tempora Somni iamque suum victrix augebat Cynthia regnum, et deformis Hiems gratos carpebat honores divitis Autumni iussoque senescere Baccho carpebat raras serus vindemitor uvas.}

Both texts change into a non-epic passage suddenly and without any preparation, starting with the word iam that is repeated later. The times given by them are very close to each other, as the Senecan one denotes the 13th of October, while the Juvenalian one refers to the end of October or the beginning of November. Both of the authors use the expression deformis hiems in an epic personification, ${ }^{29}$ while autumn is mentioned with an epithet. The wording of the two passages is similar, as both of them use past tense verbs and ablative absolutes. Moreover, while these passages focus on some meteorological phenomena, both of them describe a scene of everyday life, the content of which is a bit uncommon in Seneca's lines (iussoque senescere Baccho / carpebat raras serus vindemitor uvas), and absolutely differs from a stock epic timesetting in Juvenal (iam quartanam sperantibus aegris). If the satirist was familiar with Seneca's work as it can be supposed on the basis of a passage in Satire $6,{ }^{30}$ we can also assume the direct influence of the Senecan locus.

The central character of the turbot-story, Domitian, does not appear on the scene in this section of the mock-epic. However, he is mentioned by Juvenal several times: after the quite surprising calvus Nero (38) of the time-setting, the next two, pontifex summus (46) and Caesar (51) can be called conventional, which cannot be said about the word Atrides in line 65. Townend supposes that the original poem parodied by Juvenal used the same word to refer to Domitian; however, it was not the poet's best choice, since the younger one of the brothers was cheated on by his wife, which was also rumoured about Domitian, the brother of Titus. ${ }^{31}$ This work, the target of Juv-

${ }^{28}$ The quoted lines of the Apocolocyntosis are also mentioned by COURTNEY (n. 1) 212 and BRAUND (n. 6) 247, but neither suggests the direct influence of Seneca.

${ }^{29}$ Cf. Eden, P. T. (ed.): Seneca: Apocolocyntosis. Cambridge 1984, 69. Besides these two passages, the expression occurs only in the Punica of Silius Italicus (3. 489).

${ }^{30}$ Juv. 6. 620-623: minus ergo nocens erit Agrippinae / boletus, siquidem unius praecordia pressit / ille senis tremulumque caput descendere iussit / in caelum et longa manantia labra saliva. CLACK, J.: To Those Who Fell on Agrippina's Pen. CW 69 (1975) 46 interprets the verb descendere of the cited passage as a direct reference to Seneca's work.

${ }^{31}$ TOWNEND (n. 8) 154, n. 35. Further possible interpretations: 1) BRAUND (n. 6) 249: Juvenal foreshadows Domitian's death depicted in the last lines of the satire; 2) SWEET (n. 14) 285: Domitian is the enemy of the Romans, as were both Atridai of the Roman's ancestors. 
enal's parody can be identified thanks to a scholion of the so-called Probus, who commenting on line 94 quotes four lines from a lost poem of Statius known as De Bello Germanico, which show multiple connections to the council scene of Juvenal:

\section{lumina: Nestorei mitis prudentia Crispi et Fabius Veiento - potentem signat utrumque purpura, ter memores implerunt nomine fastos - et prope Caesareae confinis Acilius aulae.}

Crispus, Veiento and Acilius mentioned by Statius in these lines appear also in the council scene of Satire 4:

venit et Crispi iucunda senectus...

proximus eiusdem properabat Acilius aevi

cum iuvene indigno...

et cum mortifero prudens Veiiento Catullo...
Juv. 4.80

Juv. 4. 94-95

Juv. 4. 113

Moreover, it can also be assumed that a fourth member of Juvenal's council appeared in the quoted passage of Statius: if the first word of the fragment, lumina, means "eyes" here, together with the previous lost line, it can refer to L. Valerius Catullus Messalina, whose blindness is mentioned twice by Juvenal (Juv. 4. 114: numquam visae flagrabat amore puellae; 116: caecus adulator); however it cannot be declared with certainty. ${ }^{32}$ Another link between the two passages is that the old age of Q. Vibius Crispus is emphasized by both poets.

The connection between the lines quoted by Probus and Juvenal's council scene is obvious, but it is a debated question how closely Satire 4 resembles Statius' epic. While Highet and Colton consider the whole mock-epic as a parody of De Bello Germanico, ${ }^{33}$ the views of most of the scholars are not so definite ${ }^{34}$ however, it is more

\footnotetext{
${ }^{32}$ This is suggested by, among others HIGHET, G.: Juvenal's Bookcase. AJPh 72 (1951) 376; GRIFFITH (n. 19) 142-143.

${ }^{33}$ Highet (n. 32) 376: "We know nothing more of the piece, but this resemblance is close enough to make it probable that Juvenal's entire satire was a mock-heroic gibe at an epyllion in which Statius glorified the emperor and flattered his chief satellites." COLTON, R. E.: Cabinet Meeting: Juvenal's Fourth Satire. $C B 40$ (1963) 1: "This poem is a parody of Statius' prizewinning epic on Domitian's German and Dacian campaigns."

${ }^{34}$ TOWNEND (n. 8) 153: "However, the fragment of Statius' lost poem on Domitian's German war, inserted in the margin at line 94 by the crazy annotator who seems to have worked not long after the early satires were published, makes it clear that it is to some extent the source of Juvenal's catalogue of imperial amici"; BALDWIN, B.: Juvenal's Crispinus. AClass 22 (1979) 112: "Valla, commenting on Juvenal 4.94, quotes the only four lines we possess of Statius' epic De Bello Germanico [...] There are obvious reasons for thinking that Juvenal is parodying this in his register of Domitian's advisors"; SWEET (n. 14) 297-298: "Valla's citation of four hexameters from this poem is enough to permit us to recognize that the satirist had at least this one epic in mind as his target"; GRIFFITH (n. 19) 142: "That within the compass of Statius' four lines three of the eleven councillors who occur in Juvenal should have been named suffices to show the close literary dependence of satire iv on the original it parodies"; COURTNEY (n. 1) 195: "At least from 72 onwards, the satire is without doubt based on parody of Statius..."; BRAUND (n. 6) 251: "This catalogue constitutes epic parody, almost certainly of Statius' De Bello Germanico, now lost to us"; KILPATRICK (n. 12) 232 is a bit more cautious: “... an epic parody, possibly of Statius' de bello Germanico.”
} 
or less a communis opinio that to some degree Juvenal used Statius' poem. ${ }^{35}$ Without any further knowledge of the original poem, it cannot be determined how closely the satirist followed the work of Statius, but there are other possible linking points. According to Townend, the peculiar apostrophe to the Muse could also refer to Statius' epic, and he also emphasizes that the council scene can have further unidentifiable references to the De Bello Germanico. ${ }^{36}$ One can suppose that Statius could be the source of the grand style expressions used here to refer to Domitian, as induperator (29) that is unusual even in the language of epic, ${ }^{37}$ or $d u x$ magnus used ironically by the satirist - anyway, the latter is applied to Domitian by Statius in his Silvae. ${ }^{38}$

The most crucial part for the interpretation of the mock-epic is the council scene, the importance of which comes from the enumeration of the arriving advisors. ${ }^{39}$ The catalogue of the turbot-epic presents sordid "heroes" without any commonplace epic virtue: the satiric indignation becomes even more and more apparent when the deathbringer Catullus (113) and the sluggish Montanus (107) arrive instead of the pious Aeneas and the swift-footed Achilles. As it was already said before, with the representation of different aspects of moral corruption, the advisors draw a crushing picture of the emperor himself, surrounded by people like them. ${ }^{40}$ Furthermore, the invective is not only against Domitian but also against the whole regime, the most prominent men of which deal with such petty problems. And moreover, as Juvenal suggests in the last lines of the mock-epic, the assembly discussing the fate of the turbot is a council of war actually summoned by Domitian as if he would like to debate the status of the Germanic wars. ${ }^{41}$ surgitur et misso proceres exire iubentur
consilio, quos Albanam dux magnus in arcem
traxerat attonitos et festinare coactos,
tamquam de Chattis aliquid torvisque Sygambris
dicturus, tamquam ex diversis partibus orbis
anxia praecipiti venisset epistula pinna.
atque utinam his potius nugis tota illa dedisset
tempora saevitiae...
Juv. 4. 144-151

${ }^{35}$ The opinion of CURTIS (n. 26) 74 is somewhat an exception: "While we may never know how closely this satire follows Statius' account of an imperial meeting, there are nevertheless enough examples of other council scenes in epic works for this satiric version to be counted as a general subversion of a grand cliché, rather than as a direct parody of merely one source."

${ }^{36}$ TOWNEND (n. 8) 153.

${ }^{37}$ The word used repeatedly by Ennius and Lucretius does not occur in later surviving epic texts, cf. KILPATRICK (n. 12) 233: "A very rare word in extant Latin literature, but Statius may have used it in his lost epic as a compliment to Domitian."

${ }^{38}$ Stat. Silv. 3. 1. 61-63: ast ego, Dardaniae quamvis sub collibus Albae / rus proprium magnique ducis mihi munere currens / unda domi curas mulcere... HIGHET (n. 33) 365, n. 26 argues that the expression refers to the quoted lines of the Silvae.

${ }^{39}$ ThOmson, J. O.: Juvenal's Big-Fish Satire. G\&R 21 (1952) 87 suggests another possible literary source: the council of the young Ptolemy in Book 8 of Pharsalia (Luc. 8. 474-483).

${ }^{40}$ In addition to the above, see also ANDERSON (n. 3) 241: "The portraits bring into focus what the satirist implies about the reign of Domitian: that the courtiers directly reflect their master."

${ }^{41}$ ANDERSON (n. 3) 242 emphasizes the importance of this aspect. 
Crispus, Veiento and the other nine, however, are not negotiating about Chattis... torvisque Sygambris, but they are talking about the preparation of an extraordinary big fish. Juvenal suggests that the dux magnus celebrated for his successes against the Germans was concerned with such bagatelle topics (nugis - 150) during the war. The purpose of the mock-epic of Satire 4 is not only to expose the immorality of Domitian and his inner circle but also to make them ridiculous by presenting their council of war called together because of an enormous fish, consisting of men characterized by saevitia and luxuria instead of virtus, ${ }^{42}$ giving the simplest answer to the most banal question. Anderson's suggestion that the giant turbot is the metaphor of the empire seems quite convincing; however, in my interpretation, we should not seek a secondary meaning behind the enormous fish since, as it is emphasized by the poet, this case was only one of the nugae that absorbed his thoughts. The insignificance of the central problem of the turbot-epic is the main source of humour and satiric mockery.

When Juvenal declares in his peculiar invocation of the Muse that in this poem the truth will be told ("res vera agitur"), he does so as if he was making a promise that he will reveal what Domitian was actually concerned with while others were fighting the war, for which Statius wrote a panegyric epic to him. In this manner, Statius, his poem, and also flattering poetry in general become the target of Juvenal. Thus, another dark aspect of Domitian's reign is exposed: even the epic Muse is a servant of the emperor, and therefore the subject of the historical epic cannot be res vera either, similarly to the mythological epic that was opposed with Juvenal's poetry aiming to depict reality in Satire 1. As Juvenal already pointed out in his programmatic poem, the only genre that is suitable for his purpose, i.e. the direct representation of contemporary Rome, is the satire that in his fourth poem is dressed in epic clothing in order to prove that.

Gergő Gellérfi

University of Szeged

MTA-SZTE Antiquity and Renaissance: Sources and Reception Research Group

Hungary

${ }^{42}$ Saevitia and luxuria as central motifs of the satire play a crucial role in the interpretation of ANDERSON (n. 3) 232-244. 